\title{
EFFECT OF UV RADIATION AND TRISODIUM PHOSPHATE ON BACTERIAL DECONTAMINATION OF CHICKEN FILLETS
}

\author{
H.F.A. EL-DOSOKY; SHERIN S. MOSTAFA and S. SHAFIK
}

Animal Health Research Institute, Mansoura Laboratory, Mansoura,Egypt.

\section{ABSTRACT}

Received at: $21 / 2 / 2013$

Accepted: 12/3/2013
One hundred random samples of chicken fillets were collected from an automatic poultry slaughtering plant in Dakahlia Governorate just after preparation. The samples were divided into five groups, each group consists of 20 chicken fillets examined for Aerobic Plate Count (APC), Enterobacteriaceae and Most Probable Number (MPN) of coliforms. The first group dipped in 10\% Triodium phosphate (TSP) for 30 seconds where the counts were reduced by $0.75,0.78$ and $0.59 \log$ cfu/gm, the second group were decontaminated with UV radiation for a minute where reduced by $0.45,0.34$ and $0.35 \log \mathrm{cfu} / \mathrm{gm}$, the third group were decontaminated with UV radiation for three minutes where it reduced by $0.79,0.64$ and $0.67 \mathrm{log} \mathrm{cfu} / \mathrm{gm}$, The fourth group were dipped in $10 \%$ TSP for $30 \mathrm{~s}$ then exposed to UV radiation for a minute where it reduced by $1.30,1.31$ and $1.14 \log$ cfu/gm and The fifth group were dipped in 10\% TSP for 30s then exposed to UV radiation for three minutes where it reduced by $1.44,1.54$ and $1.51 \mathrm{log} \mathrm{cfu} / \mathrm{gm}$ respectively. The obtained results revealed that there were a significant reduction when compared with those before decontamination statistically for all groups $(\mathrm{P}<0.05)$. In conclusion, application of $10 \%$ TSP\&UV reduced the aforementioned bacteria significantly $(\mathrm{P}<0.05)$, Therefore this study was focused on the effect of $10 \%$ TSP and/or UV radiation on bacterial populations, Enterobacteriaceae and Coliforms counts in chicken fillets.

Key words: UV radiation, Chicken filets, Enterobacteriaceae and Coliforms

\section{INTRODUCTION}

Chicken products can be contaminated during preparation with pathogens as E. coli, Salmonella spp. and C. jejuni which are present in chicken intestine Anang et al. (2007) and Hong et al. (2008). There was a growing interest in using UV radiation for food preservation particularly as UV disinfection does not require chemicals or heat and relatively inexpensive McDonald et al. (2000) and Lamikanra et al. (2005) added that UV technology used as an alternative to chemical sterilization in food products and so Wallner et al. (1994) and FDA (2007) stated that UV 220-300nm has germicidal effect on the surface of fresh meat and poultry and approved for use on food products to control surface contamination. Berrang et al. (2001) not detect Coliforms and E. coli while total aerobic count in breast meat were $1.3 \log _{10} \mathrm{cfu} / \mathrm{gm}$. F.S.I.S. (1992) and Capita et al. (2002) mentioned that 8-10\% TSP $(\mathrm{PH}>11.5)$ were effective in poultry carcass decontamination, while UV kills bacteria by cell wall degradation Bachman (1975). Somers et al. (1994) and Federight et al. (1995) stated that (10-12\% TSP) reduce total aerobes, E.coli and Enterobacteriaceae by more than $2 \log$ cycles in poultry carcass. Stermer et al. (1987) reported 2 log reduction in bacteria on fresh beef by UV radiation. Susan et al. (1995) concluded that UV radiation reduce $80.5 \%$ of the inoculated poultry skin with $S$. typhimurium. Wang et al. (1998) and Zeong et al. (1998) declared that spraying chicken carcass with $10 \%$ TSP reduce the total aerobes by $0.74 \quad \log _{10}$ cfu /carcass and S. typhimurium decreased by $2 \log$ cycles. Gabriela et al. (2001) proved that $12 \% \mathrm{TSP}$ and UV for $25 \mathrm{~min}$. reduce APC by 1.03 and $1.60 \log$ cfu/egg, while UV exposure for $1 \mathrm{hr}$ gives no growth. Whyte et al. (2001), applied 10\%TSP for 15 seconds. which reduce E.coli and Enterobacteriaceae by 1.95 and $1.86 \log _{10} \mathrm{cfu} / \mathrm{gm}$. Kim et al. (2002) stated that UV at $254 \mathrm{~nm}$ reduce inoculated skinless chicken with S. typhimurium and E.coli $O_{157}: H_{7}$ by 0.07 and 0.24 $\log \mathrm{cfu} / \mathrm{cm}^{2}$ after one minute and 0.22 and $0.26 \log$ $\mathrm{cfu} / \mathrm{cm}^{2}$ for two minutes. Guerrero and Babosa (2004) stated that UV reduce the microbial load by blockage DNA transcription and replication. Isohanni and Lyhs (2009) achieved $0.7 \log \mathrm{cfu} / \mathrm{ml}$ reduction for $C$. jejuni by UV light on broiler fillets. Chun et al. (2010) obtained reductions of 1.26 and $1.19 \log _{10} \mathrm{cfu} / \mathrm{gm}$ for C. jejuni and S. typhimurium by UV treatment of chicken breast, while UV light $(254 \mathrm{~nm})$ at $0.5-0.4 \mathrm{~J}$. $/ \mathrm{cm}$ reduce cocktail of Salmonella spp., L.monocytogenes and Staph. aureus on breast fillets by $0.4 \mathrm{log} \mathrm{cfu} / \mathrm{gm}$ Sommers et al. (2010) and Haughton et al. (2011) mentioned that raw chicken fillets treated with UV at $0.192 \mathrm{~J} / \mathrm{cm}^{2}$ reduce E.coli, total viable counts and enterobacteriaceae by 0.98 , 1.76 and $1.29 \mathrm{log} \mathrm{cfu} / \mathrm{gm}$ and fillets color was not 
significantly affected. Keklik et al. (2011) achieved reduction from $0.87-1.43 \mathrm{log} \mathrm{cfu} / \mathrm{ml}$ rinse solution after $30-180$ s treatment by pulsed UV light where the temperature ranged from $11.1-44.1^{\circ} \mathrm{c}$.

\section{MATERIALS and METHODS}

\section{A- Sampling:}

A total number of 100 chicken breast fillets were collected from an automatic poultry processing plant in Dakahlia, Governorate after complete preparation, the chicken breast fillets were packed in polyethylene film pack and stored at $4^{0} \mathrm{C}$ and used for the experiment upon receipt to the laboratory. The examined samples were divided into five groups (20 chicken breast fillets for each group).The first group were dipped in $10 \%$ TSP for $30_{\mathrm{s}}$, the second group were exposed to UV irradiation at dose of 0.192 $\mathrm{J} / \mathrm{cm}^{2}$ and $254 \mathrm{~nm}$ wave length for one minute, the third group were exposed to UV irradiation at dose of $0.192 \mathrm{~J} / \mathrm{cm}^{2}$ and $254 \mathrm{~nm}$ wave length for three minutes, the fourth group were dipped in $10 \%$ TSP for $30_{\mathrm{S}}$ and left ten minutes till fluid drainage then exposed to UV irradiation at dose of $0.192 \mathrm{~J} / \mathrm{cm}^{2}$ and $254 \mathrm{~nm}$ wave length for one minute, the last group were dipped in $10 \%$ TSP for $30_{\mathrm{S}}$ and left ten minutes till fluid drainage then exposed to UV irradiation at dose of $0.192 \mathrm{~J} / \mathrm{cm}^{2}$ and $254 \mathrm{~nm}$ wave length for three min. UV irradiation was performed using unfiltered germicidal emitting lamps, The chicken fillets were placed on a stainless-steel tray and irradiated on both the upper and lower surfaces at a distance of $18 \mathrm{~cm}$, six germicidal emitting lamps were placed on both sides and the UV lamps were warmed up for $30 \mathrm{~min}$. before irradiation process. UV intensity was determined using UV radiometer calibrated at $254 \mathrm{~nm}$ and the UV irradiation dose was changed by altering exposure time. UV irradiation was performed in the darkroom to minimize photoreactivation of the pathogenic bacteria after irradiation.

\section{B- Bacteiological analysis:}

Following TSP\&UV irradiation $25 \mathrm{gm}$ of each examined samples (before and after treatment) were removed using a sterile scalpel and mixed with $225 \mathrm{ml}$ of peptone water $(0.1 \%$ sterile peptone $)$ in a sterile stomacher bag. The samples were then homogenized using a stomacher for three minutes, filtered through a sterile cheese cloth, and diluted with peptone water for microbial count, after two to six serial dilutions $(0.1 \mathrm{ml})$ were spread on specific media to determine the following:

\section{1- The aerobic plate count (APC).}

\section{2- Enterobacteriaceae count.}

According to the methods recommended by APHA (2001).

\section{3- Most Probable Number (MPN) of Coliforms.}

According to the method recommended by FDA (2005).

The Microbial counts were expressed as log cfu/gm.

\section{RESULTS}

Table 1: Log mean viable counts of microbial contamination for the treated chicken fillets with $10 \%$ TSP $(n=20)$.

\begin{tabular}{cccc}
\hline $\begin{array}{c}\text { Microbial count } \\
\log \text { mean } \pm \text { S. } E\end{array}$ & $\begin{array}{c}\text { Counts before TSP } \\
\text { treatment }\end{array}$ & $\begin{array}{c}\text { Counts after TSP } \\
\text { treatment }\end{array}$ & Log red. \\
\hline Aerobic plate count & $4.83 \pm 0.80$ & $4.08 \pm 0.70^{*}$ & 0.75 \\
\hline Enterobacteriaceae count & $4.38 \pm 0.72$ & $3.60 \pm 0.30^{*}$ & 0.78 \\
\hline Coliform count & $3.32 \pm 0.48$ & $2.73 \pm 0.48^{*}$ & 0.59 \\
\hline $\begin{array}{l}\text { number of examined samples }, \mathrm{TSP}=\text { trisodium phosphate, } \\
\text { significantly important }(\mathrm{p}<0.05) .\end{array}$ & red. $=$ reduction, $*$ the results were
\end{tabular}

Table 2: Log mean viable counts of microbial contamination for the treated chicken fillets with UV for one minute $(\mathrm{n}=20)$.

\begin{tabular}{cccc}
\hline $\begin{array}{c}\text { Microbial count } \\
\log \text { mean } \pm \text { S.E }\end{array}$ & $\begin{array}{c}\text { Counts before UV } \\
\text { treatment }\end{array}$ & $\begin{array}{c}\text { Counts after UV } \\
\text { treatment }\end{array}$ & Log red. \\
\hline Aerobic plate count & $4.66 \pm 0.34$ & $4.21 \pm 0.65^{*}$ & 0.45 \\
\hline Enterobacteriaceae count & $4.26 \pm 0.70$ & $3.92 \pm 0.60^{*}$ & 0.34 \\
\hline Coliform count & $3.11 \pm 0.90$ & $2.76 \pm 0.85^{*}$ & 0.35 \\
\hline
\end{tabular}


Table 3: Log mean viable counts of microbial contamination for the treated chicken fillets with UV for three minutes $(n=20)$.

\begin{tabular}{cccc}
\hline $\begin{array}{c}\text { Microbial count } \\
\log \text { mean } \pm \text { S.E }\end{array}$ & $\begin{array}{c}\text { Counts before } \\
\text { treatment }\end{array}$ & $\begin{array}{c}\text { Counts after UV } \\
\text { treatment }\end{array}$ & Log red. \\
\hline Aerobic plate count & $4.71 \pm 0.53$ & $3.92 \pm 0.70^{*}$ & 0.79 \\
\hline Enterobacteriaceae count & $4.34 \pm 0.90$ & $3.70 \pm 0.30^{*}$ & 0.64 \\
\hline Coliform count & $3.53 \pm 0.84$ & $2.86 \pm 0.78^{*}$ & 0.67 \\
\hline
\end{tabular}

Table 4: Log mean viable counts of microbial contamination for treated chicken fillets with $10 \%$ TSP\&UV for one minute $(n=20)$.

\begin{tabular}{cccc}
\hline $\begin{array}{c}\text { Microbial count } \\
\text { log mean } \pm \text { S.E. }\end{array}$ & $\begin{array}{c}\text { Counts before } \\
\text { treatment }\end{array}$ & $\begin{array}{c}\text { Counts after TSP\& UV } \\
\text { treatment }\end{array}$ & Log red. \\
\hline Aerobic plate count & $4.80 \pm 0.95$ & $3.50 \pm 0.40^{*}$ & 1.30 \\
\hline Enterobacteriaceae count & $4.58 \pm 0.75$ & $3.27 \pm 0.65^{*}$ & 1.31 \\
\hline Coliform count & $3.34 \pm 0.78$ & $2.20 \pm 0.30^{*}$ & 1.14 \\
\hline
\end{tabular}

Table 5: Log mean viable counts of microbial contamination for treated chicken fillets with10\%TSP\&UV for three minutes $(n=20)$

\begin{tabular}{cccc}
\hline $\begin{array}{c}\text { Microbial count } \\
\text { log mean } \pm \text { S.E. }\end{array}$ & $\begin{array}{c}\text { Counts before } \\
\text { treatment }\end{array}$ & $\begin{array}{c}\text { Counts after TSP\& UV } \\
\text { treatment }\end{array}$ & Log red. \\
\hline Aerobic plate count & $4.76 \pm 0.38$ & $3.32 \pm 0.30^{*}$ & 1.44 \\
\hline Enterobacteriaceae count & $4.41 \pm 0.04$ & $2.87 \pm 0.48^{*}$ & 1.54 \\
\hline Coliform count & $3.36 \pm 0.90$ & $1.85 \pm 0.30^{*}$ & 1.51 \\
\hline
\end{tabular}

\section{DISCUSSION}

In this study the achieved results showed that the inactivation of bacterial contamination on chicken breast fillets by UV and/or TSP increased significantly $(\mathrm{P}<0.05)$ with increasing UV radiation time or dipping in TSP, where the results in table (1) declared that $10 \%$ TSP reduce the APC, Enterobacteriaceae and MPN of coliforms counts from $4.83 \pm 0.80,4.38 \pm 0.72$ and $3.32 \pm 0.48$ to $4.08 \pm 0.70,3.60 \pm 0.30$ and $2.73 \pm 0.48$ with mean $\log$ reduction $0.75,0.78$ and $0.59 \mathrm{log}$ cfu/gm respectively the results were significantly reduced $(\mathrm{P}<0.05)$, these results were in accordance with F.S.I.S. (1992); Somers et al. (1994); Federight et al. (1995); Wang et al. (1998); Zeong et al. (1998); Whyte et al. (2001) and Capita et al. (2002). The results in table (2) suggested that UV radiation can be useful in improving the microbial safety of chicken breast fillets without impairing meat quality where exposure to UV radiation for one minute reduce APC, Enterobacteriaceae and MPN of coliform counts from $4.66 \pm 0.34, \quad 4.26 \pm 0.70$ and $3.11 \pm 0.90$ to
$4.21 \pm 0.65,3.92 \pm 0.60$ and $2.76 \pm 0.85$ with mean $\log$ reduction $0.45,0.34$ and $0.35 \log \mathrm{cfu} / \mathrm{gm}$ respectively. Meanwhile increasing UV exposure time decrease the population of the examined bacteria on chicken fillets where the germicidal properties of UV radiation on bacteria are due to the DNA damage done by UV radiation which causes damage to cross-linking between neighbouring pyrimidine bases In the same DNA strand Sastry et al. (2000). Thus, the formation of hydrogen bonds to the purine bases on the opposite strand is impaired due to the mutation, thereby blocking DNA transcription and eventually leading to cell death Unluturk et al. (2008). The results of bacterial decontamination in table (3) were $4.71 \pm 0.53,4.34 \pm 0.90$ and $3.53 \pm 0.84$ which reduced to $3.92 \pm 0.70,3.70 \pm 0.30$ and $2.86 \pm 0.78$ with mean $\log$ reduction $0.79,0.64$ and $0.67 \mathrm{log} \mathrm{cfu} / \mathrm{gm}$ for APC, Enterobacteriaceae and MPN of coliforms respectively. The results in table (2) \& table (3) were reduced significantly when compared with those recorded before decontamination $(\mathrm{P}<0.05)$ and similarly to those obtained by Bachman (1975); Stermer et al. (1987); McDonald et al. (2000); Kim et al. (2002); Guerrero and Babosa (2004); 
Lamikanra et al. (2005); FDA (2007); Isohanni and Lyhs (2009); Chun et al. (2010); Sommers et al. (2010); Haughton et al. (2011) and Keklik et al. (2011).

Our results in table (4) clearly showed that UV\&TSP decreased the bacterial population on chicken fillets where the counts after dipping in 10\%TSP and exposure to UV radiation for one minute reduced from $4.80 \pm 0.95,4.58 \pm 0.75$ and $3.34 \pm 0.78$ to $3.50 \pm 0.40,3.27 \pm 0.65$ and $2.20 \pm 0.30$ with mean $\log$ reduction 1.30,1.31 and $1.14 \mathrm{log} \mathrm{cfu} / \mathrm{gm}$ for APC, Enterobacteriaceae and MPN of coliforms respectively and after dipping in 10\% TSP and exposure to UV radiation for three minutes in table (5) the counts were reduced from $4.76 \pm 0.38$, $4.41 \pm 0.04$ and $3.36 \pm 0.90$ to $3.32 \pm 0.30,2.87 \pm 0.48$ and $1.85 \pm 0.30$ with mean $\log$ reduction $1.44,1.54$ and $1.51 \log \mathrm{cfu} / \mathrm{gm}$ respectively, the results were significantly reduced in comparison with those recorded before decontamination $(\mathrm{P}<0.05)$ and were in accordance with those obtained by Gabriela et al. (2001); Kim et al. (2002); Isohanni and Lyhs (2009) and Haughton et al. (2011) However few studies have been conducted on the application of UV\&TSP for the inactivation of bacterial contamination in chicken fillets.

In summary, the germicidal effect of $10 \%$ TSP \& UV treatment applied on the surface of raw boneless skinless chicken breast fillets reduce the number of bacterial cells significantly. Thus 10 \% TSP \& UV radiation process could be used in raw poultry processing plants to lessen the contamination chances of fully prepared poultry products.

\section{REFERENCES}

American Public Health Association (APHA) (2001): Compendium of methods for the microbiological examination of food, Washington, DC

Anang, D.M.; Rusul, G.; Bakar, J. and Ling, F.H. (2007): Effect of lactic acid and lauricidin on the survival of L. monocytogenes, S. entertidis and $E$. coli $O_{157} ; H_{7}$ in chicken breast stored at $4^{0}$ c. Food control, 18 (8), 961-969.

Bachman, R. (1975): Sterilization by intense UV radiation. Brow Boveri Rev. 62: 206-209.

Berrang, M.E.; Ladely, S.R. and Buhr, R.J. (2001): Presence and level of Campylobacter, Coliforms, E. coli and total aerobic bacteria recovered from broiler parts with and without skin. J. Food protection, 64; 2: 184-188.

Capita, R.; Alonso-Calleja, C.; delCaminoGarciaFernandez, M. and Moreno, B. (2002): Activity of trisodium phosphate compared with sodium hydroxide wash solutions against $L$. monocytogenes attached to chicken skin during refrigerated storage. Food Microbiology. 19 (1), 57-63.

Chun, H.H.; Kim, J.Y.; Lee, B.D.; Yu, D.J. and Song, K.B. (2010): Effect of UV-C irradiation on the inactivation of inoculated pathogens and quality of chicken breasts during storage. Food Control, 21: 276-280.

Federight, M.; Cappelier, J.M.; Rossero, A.; Coppen, P. and Denis, J.C. (1995): Evaluation de 1 'effect d'un traitment de decontamination de carcasses de poulets, vis-à-vis des Campylobacter thermotolerants. Sci. Aliment. 15: 393-401.

Food and Drug Adiministration (FDA) (2005): Staphylococcus aureus, Bad Bug Book, Foodborne Pathogenic Microorgaisms and Natural Toxins Handbook (1992 / updated 2005), USFDA/FDA, Center for Food Safety $\&$ Applied Nutrition.

Food and Drug Adiministration (FDA) (2007): Irradiation in the production processing and handling of food;21 CER. Part 179.39. Code of Federal Regulations, 3: 439-440.

Food Safety and Inspection Service (F.S.I.S.) (1992): Permits Trisodium Phosphate in poultry plants. Food Safety and Inspection Service Background Document. October.

Gabriela, Z. Favier; Maria, Escudero E. and Ana, M.De Guzman (2001): Effect of chlorine, sodium chloride, Trisodium phosphate and Ultraviolet radiation on the reduction of Yersinia enterocolitica and mesophilic aerobic bacteria from eggshell surface. J. of Food Protection, 64; 10: 1621-1623.

Guerrero-Beltran, J.A. and Babosa, G.V. (2004): Review; advantage and limitations on processing food by UV light. Food Sci. Technol. Int. 10: 137-147.

Haughton, P.N.; Lyng, J.G.; Cronin, D.A.; Morgan, D.J.; Fanning, S. and Whyte, P. (2011): Efficacy of UV light treatment for the microbiological decontamination of chicken associated packaging and contact surfaces. J. Food Protection, 74; 4: 565-572.

Hong, Y.H.; Ku, K.J.; Kim, M.K.; Won, M.S.; Chung, K.S. and Song, K.B. (2008): Survival of E. coli $\mathrm{O}_{157} ; \mathrm{H}_{7}$ and inoculated on chicken by aqueous chlorine dioxide treatment. J. Microbiology and Biotechnology, 18(4): 742-745.

Isohanni, P.M. and Lyhs, U. (2009): Use of Ultraviolet irradiation To reduce $C$. jejuni on broiler meat. Poultry Sci. 88: 661-668.

Keklik, N.M.; Demirci, A. and Bock, R.G. (2011): Surface decontamination of whole chicken carcasses using Pilot-Scale pulsed UV light system transactions of the ASABE.54; 4: 9931000.

Kim, T.; Silva, J.L. and Chen, T.C. (2002): Effect of UV irradiation on selected pathogens in 
peptone water and on stainless steel and chicken meat. J. of Food Protection, 65; 7: 1142-1145.

Lamikanra, O.; Kueneman, D.; Ukuku, D. and BettGarber, K.L. (2005): Effect of processing under ultraviolet light on the shelflife of fresh cut cantaloupe melon. J. of Food Science, 70; 9: 534-539.

McDonald, K.F.; Curry, R.D.; Clavenger, T.E.; Unklesbay, K.; Eisenstark, A.; Golden J. and Morgan, R.D. (2000): A comparison of pulsed and continuous UV light sources for the decontamination of surfaces. IEEE Trans. Plasma Sci. 28: 1581-1587.

Sastry, S.K.; Datta, A.K. and Worobo, R.W. (2000): Ultraviolet light, Journal of Food Science Supplement. 65, 12: 90-92.

Somers, E.B.; Schoeni, J.I. and Wong, A.C.L. (1994): Effect of trisodium phosphate on biofilm and planktonic cells of C. jejuni, E.coli $\mathrm{O}_{157} \mathrm{H}_{7} ; \mathrm{L}$. monocytogenes and $S$. typhimurium. Int. J. Food Microbiology. 22: 269-276.

Sommers, C.H.; Sites, J.E. and Musgrove, M. (2010): Ultraviolet light $(254 \mathrm{~nm})$ inactivation of pathogens on foods and stainless steel surfaces. J. Food Safety 30; 2: 470-479.

Stermer, R.A.; Lasater-Smith, M. and Brasington, C.F. (1987): Ultraviolet radiation and effective bactericide for fresh meat. J. Food Protection 50: 108-111.
Susan S. Sumner; Eva, A. Wallner-Pendleton; Glenn W. Froning and La Verne E. Stetson (1995): Inhibition of $S$. typhimurium on agar medium and poultry skin by ultraviolet energy. J. Food Protection, 59; 3: 319-321.

Unluturk, S.; Atilgan, M.R.; Baysal, A.H. and Tari, C. (2008): Use of UV radiation as a non-thermal process for liquid egg products (LEP) Journal of engineering. 85; 4: 561-568.

Wallner-Pendleton, E.A.; Sumner, S.S.; Froning, G.W. and Stetson, L.E. (1994): The use of Ultraviolet radiation to reduce Salmonella and psychrotrophic bacterial contamination on poultry carcasses. Poultry Sci., 73: 1327-1333.

Wang Weichi; Li Yan Bin; Slavik, M.F. and Hua Xiong (1998): Trisodium phosphate and Cetylpyridinium chloride spraying on chicken skin to reduce attached $S$. typhimurium. J. Food Protection. 60; 8: 992-994.

Whyte, P.; Collens, DJ.; McGill, K.; Monahan, C. and OMahony, H. (2001): Quantitative investigation of the effects of chemical decontamination procedures on the microbiological status of broiler carcasses during processing. J. Food Protection. 64; 2: 179-183.

Zeong P.Y.; Yanbin, L.I. and Michael, S. (1998): Use of antimicr- obial spray applied with insideoutside bird washer to reduce bacterial contamination on prechilled chicken carcasses. J. Food Protection 61; 7: 829-832.

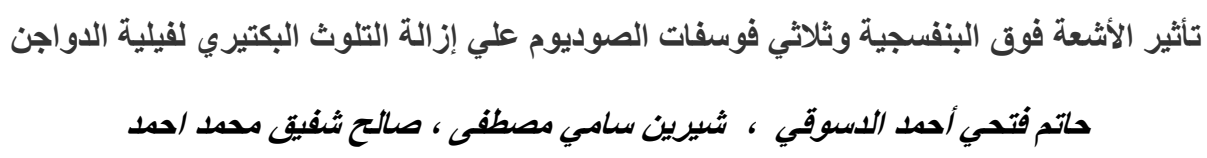

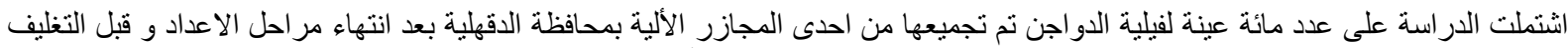

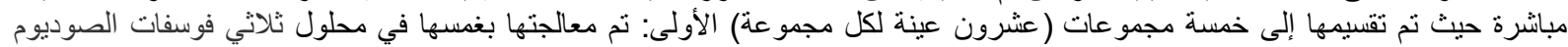

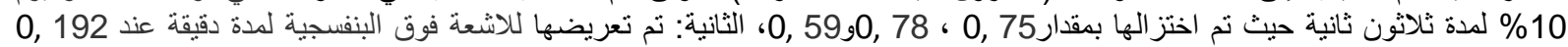

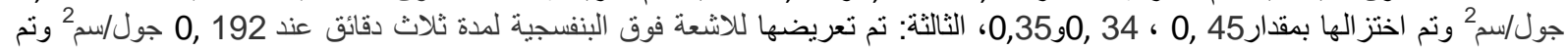

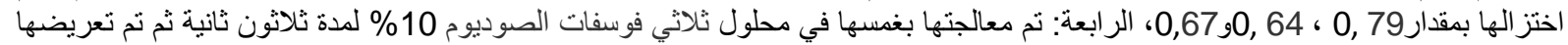

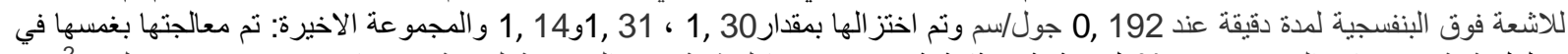

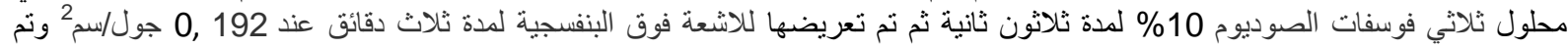

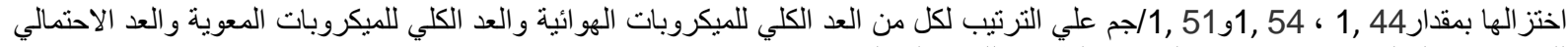
للميكروبات القولونية دون تغير في الصفات الطبيعية للحوم المعالجة. 